\title{
IN SILICO CHARACTERIZATION OF HUMAN INTERFERON ALPHA/BETA RECEPTOR 2 (ISOFORM A, B AND C) PROTEIN
}

\author{
Ambreen Javed, Gulshan Ara Trali*, Hassan Burair Abbas, Alia Sadiq \\ HITEC-Institute of Medical Sciences, Taxila/National University of Medical Sciences (NUMS) Pakistan, *Swat Medical College, Saidu Sharif, Swat Pakistan
}

\section{ABSTRACT}

Objective: To predict the tertiary structure of human interferon alpha/beta receptor 2 protein.

Study Design: Structure prediction by using bio informatics tools.

Place and Duration of Study: Department of Biochemistry, Swat Medical College (STMC), Saidu Shareef, Swat, Pakistan, from Aug 2019 to Dec 2019.

Methodology: All protein sequences of human interferon alpha/beta receptor 2 (isoforma, $b$ and c) (IFNAR-2) were retrieved through the BLAST search (The Basic Local Alignment Search Tool) from available databases 'NCBI' (National Centre for Biotechnology Information) and 'Uni Prot KB' (The Universal Protein Resource). Sequence alignment was conducted by using Clustal Omega, to get the consensus sequence for IFNAR-2 protein. Consensus protein sequence of human IFNAR-2 was used for the prediction of the three-dimensional structure by employing Swiss-Model Server. Moreover, subcellular localization analysis was also performed by using CELLO2GO program.

Results: Structural model of human IFNAR-2 protein was predicted and evaluated by Ramachandran dimension. Cellular localization of tertiary topological domains of the predicted models were revealed probability of localization of IFNAR-2 protein (isoform a, b \& c) is highest in the plasma membrane due to the presence of the transmembrane alpha helical regions.

Conclusion: This study predicted the tertiary structural dimensions of human IFNAR-2 protein, including the specific topological domains that contribute towards the subcellular compartmentalization and functional characteristics.

Keywords: IFNAR-2 protein, In silico analysis, Subcellular compartmentalization, Three-dimensional structure, Transmembrane helix.

How to Cite This Article: Javed A, Trali GA, Abbas HB, Sadiq A. In Silico Characterization of Human Interferon Alpha/Beta Receptor 2 (Isoform A, B And C) Protein. Pak Armed Forces Med J 2021; 71(6): 2091-2094. $\quad$ Doi: https://doi.org/10.51253/pafmj.v71i6.6571

This is an Open Access article distributed under the terms of the Creative Commons Attribution License (https://creativecommons.org/licenses/by-nc/4.0/), which permits unrestricted use, distribution, and reproduction in any medium, provided the original work is properly cited.

\section{INTRODUCTION}

Interferon (IFN) receptors are a part of the helical cytokine receptor system. The IFNAR-2 genes encode multiple isoforms..$^{1-3}$ Studies revealed that four IFNAR2 gene transcripts (mRNAs) code for three different isoforms (three different polypeptides) through exon rearrangement, splicing and other post-transcriptional modifications. These isoforms (polypeptides) sharea common extracellular domain, 2,4 and include (1) a long trans-membrane transcript, (2) a short trans-membrane transcript and (3) a soluble transcript. 2,5 A few studies describethe contribution of these isoform of IFNAR-2 to wards the ligand based interactions, involving IFN $\beta$ and IFNa. 26,7 There is inssufficient information about their structure in the available literature. In the previous study we had investigated the primary and secondary structural motifs of IFNAR-2 protein usingan in silicostudy design. ${ }^{8}$ The presentstudy is an extension of the previous research project. Thisstudy has been designed to predict the three-dimensional protein model

Correspondence: Dr Gulshan Ara Trali, Department of Biochemistry, Swat Medical College, Khyber Pakhtunkhwa Pakistan

Received: 14 Apr 2021; revision received: 27 Dec 2021; accepted: 28 Dec 2021 andsubcellular localisation of human interferon alpha/ beta receptor 2 protein by employing bioinformatics tools for protein structure modelling.

\section{METHODOLOGY}

This study was conducted at the Department of Biochemistry, Swat Medical College (STMC), Saidu Shareef, Swat, from August to December 2019, following the approval by the Ethical Review Board (ERB) (ERB approval certificate No 951/RWP). The in silico bioinformatics technique was used to predict and analyse the protein structure of human IFNAR-2 protein. The following protein sequences of human IFNAR-2 were retrieved from NCBI (https://www. ncbi.nlm. nih.gov/) and uniport (https://www.uniprot.org/) databases, (1) interferon alpha/beta receptor 2 isoform a, (NCBI Reference Sequence: NP_001276054.1, Uni ProtKB-P48551), (2) Interferon alpha/beta receptor 2 isoform b, (NCBI Reference Sequence: NP_997467.1, UniProtKB-P48551-2), (3) interferon alpha/beta receptor 2 isoform c (NCBI Ref. Sequence: NP_001276057.1, UniProtKB-P48551-3).

The sequence alignment was done by Clustal Omega (Multiple sequence alignment tool), version: 
1.2.4 (https://www.ebi.ac.uk/Tools/msa/clustalo/). The resultingconsensus sequencewas used for further analysis. Swiss-Model Server was applied to find out the structural dimensions of human interferon alpha/ beta receptor 2 protein by employing consensus protein sequence. ${ }^{9}$ The predicted modelwasfurther investigated for reliability and quality testing by Ramachandran plot (version 2.0). Conformational statistics of the structural backbone of the predicted model were quantified bytorsion angles (phi, and psi, $\Psi$ ). QMEAN score was applied to test the absolute quality of protein model. Volume Area Dihedral Angle Reporter (VADAR) analysis was performed to assess the hydrophobic and hydrophilic characteristic features of the model. ${ }^{10}$ Transmembrane regions of human IFNAR-2 protein isoform $\mathrm{a}, \mathrm{b}$ and $\mathrm{c}$ proteins were predicted by employing TM finder program (http://www.cbs.dtu. $\mathrm{dk} /$ services/TMHMM-2.0/). ${ }^{10}$ As a rule, the number of amino acids, contributing towards the hydrophobic and hydrophilic characters should have their mean values above the set threshold, classifying them as "Transmembrane participating amino acids". Analysis of subcellular localization of human IFNAR-2 isoform $\mathrm{a}, \mathrm{b} \& \mathrm{c}$ proteins was alsoconducted by using CELLO2 Go program. ${ }^{11}$

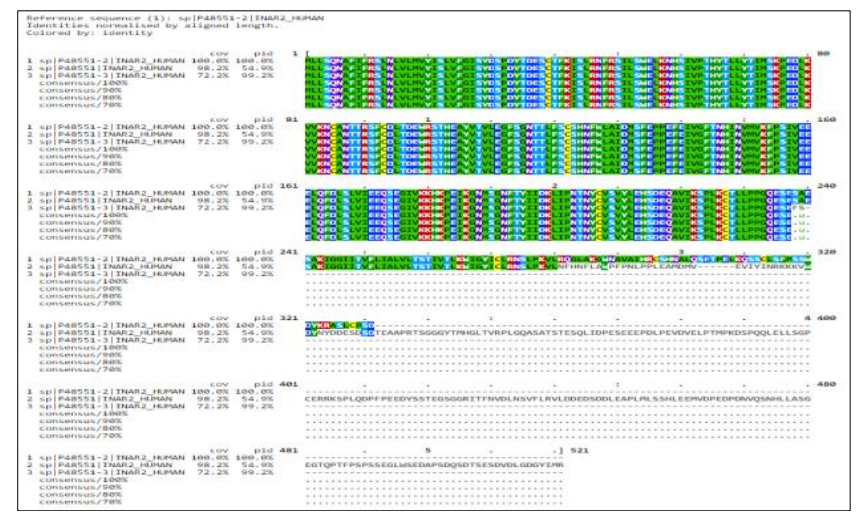

Figure-1: Protein sequences alignment of human IFNAR-2 isoforms $a, b$ and $c$ proteins.

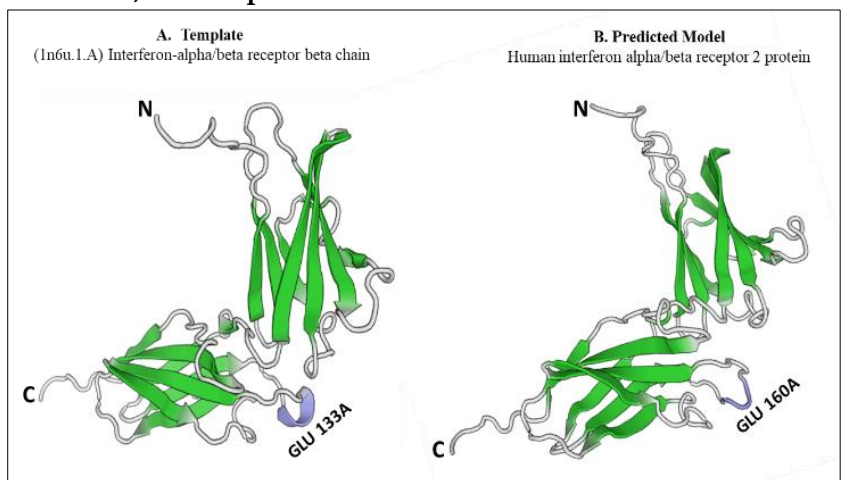

Figure-2: Predicted model of human interferonalpha/beta receptor 2protein

\section{RESULTS}

The protein sequences of human IFNAR-2 isoform $\mathrm{a}, \mathrm{b}$ and $\mathrm{c}$,retrieved from NCBI and Uniprotwere aligned toappreciate the sequence similarity (Figure-1). Human interferon alpha/beta receptor 2 isoform, a protein sequence (UniProtKB-P48551) used to predict the model, is given below:

>sp|P48551|INAR2_Human Interferon alpha/beta receptor 2 OS=Homo sapiens OX=9606GN=IFNAR2 $\mathrm{PE}=1 \mathrm{SV}=1$

MLLSQNAFIFRSLNLVLMVYISLVFGISYDSPDY TDESCTFKISLRNFRSILSWELKNHSIVPTHYTLLYTI MSKPEDLKVVKNCANTTRSFCDLTDEWRSTHEAYV TVLEGFSGNTTLFSCSHNFWLAIDMSFEPPEFEIVGFT NHINVMVKFPSIVEEELQFDLSLVIEEQSEGIVKKHK PEIKGNMSGNFTYIIDKLIPNTNYCVSVYLEHSDEQA VIKSPLKCTLLPPGQESESAESAKIGGIITVFLIALVLTS TIVTLKWIGYICLRNSLPKVLNFHNFLAWPFPNLPPL EAMDMVEVIYINRKKKVWDYNYDDESDSDTEAAP RTSGGGYTMHGLTVRPLGQASATSTESQLIDPESEEE PDLPEVDVELPTMPKDSPQQLELLSGPCERRKSPLQ DPFPEEDYSSTEGSGGRITFNVDLNSVFLRVLDDEDS DDLEAPLMLSSHLEEMVDPEDPDNVQSNHLLASGE GTQPTFPSPSSEGLWSEDAPSDQSDTSESDVDLGDG YIMR

Template selection was based on sequence similarity. The three-dimensional structure analysis was conducted by using "Swiss-Model server". Results revealed a predicted model with 26 templates. The Beta chain (1n6u.1.A) of the interferon-alpha/beta receptor template showed $100 \%$ sequence identity, therefore it was used to build the model. The predicted model of human interferon alpha/beta receptor 2 a (Figure-2) was evaluatedby using QMEAN score to assess the global and stereo-chemical properties of the predicted protein model. The reliability of the predicted model ranges from $0-1$. Our results showed that the predicted model was of good quality and confirmed by Ramachandran plot (Psi/Phi angels) (Table).

Transmembrane localization was predicted by transmembrane helices finder (bioinformatic tool TMHMM Server v.2.0) for all three IFNAR-2isoforms (isoform $a, b, c)$. Results revealed maximum sequence similarity in all three isoforms, with a variation in their secondary structures, particularly the transmembrane helices. This accounts for their localization in the membranous structures of the cells. Our results showed one transmembrane helix to be present in isoform aand c, and two transmembrane helices in isoform $b$ (Figure$3)$. The predicted sub-cellular localization of trans- 
Table: Structure assessment of the predicted model of human IFNAR-2 protein.

\begin{tabular}{l|c|c|c|c|c}
\hline Protein name & Sequence length & Sequence Identity & GMQE & QMEAN & Ramachandran Score \\
\hline $\begin{array}{l}\text { IFNAR-2a (Interferon alpha/beta } \\
\text { receptor 2 isoform a) }\end{array}$ & 515 aa & $100 \%$ & 0.33 & -3.55 & $82.69 \%$ Favoured \\
\hline $\begin{array}{l}\text { IFNAR-2b (Interferon alpha/beta } \\
\text { receptor 2 isoform b) }\end{array}$ & 331 aa & $100 \%$ & 0.67 & -3.59 & $82.69 \%$ Favoured \\
\hline $\begin{array}{l}\text { IFNAR-2c (Interferon alpha/beta } \\
\text { receptor 2 isoform c) }\end{array}$ & 239 aa & $100 \%$ & 0.84 & -3.38 & $84.29 \%$ Favoured \\
\hline
\end{tabular}

membrane helicesin isoform $\mathrm{a}, \mathrm{b}$ and $\mathrm{c}$ described their function. In addition, CELLO2GO program was also used to study subcellular localization for all three isoforms $(\mathrm{a}, \mathrm{b}, \mathrm{c})$. According to these results, isoform $2 \mathrm{~b}$ had $77.9 \%$ localization probability in the plasma membrane when compared to isoform a $(40.4 \%)$ and c $(44.1 \%)$ (Figure-4). Only isoform a had nuclear localization. Isoform c was more abundant in the extracellular space as compared to isoform a, being more cytoplasmic. Cytoplasmic proteinshas more potential as drug targets than the surface membrane proteins. ${ }^{11}$ Results also revealed that all three isoforms of IFNAR-2 protein were also found in Cytoplasm, Golgi, Endoplasmic reticulum, Lysosomal compartments and Mitochondria.

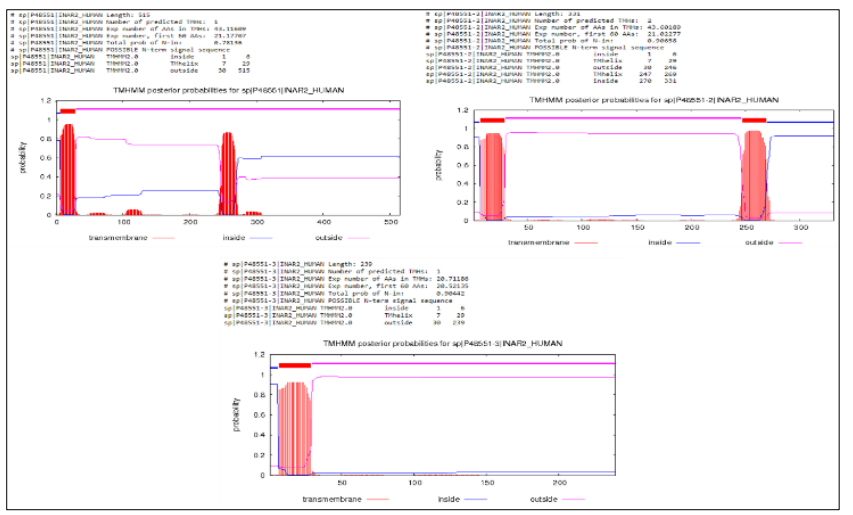

Figure-3: Predicted transmembrane regions of human IFNAR-2 (isoform $a, b$ and $c$ ) protein.

\section{DISCUSSION}

Interferons are a family of cytokines that contribute in complex and organized defence networking of the body.12-14 Information about their protein structure is necessary to understand their functional mechanisms at the cellularlevel, involving various biological functions. 8,15 Human interferon alpha/beta receptor 2 protein has three different isoforms, coded from the same gene, having different functions. This led us to investigate their structural, cellular and subcellular localization to understand the key features, which impart specific functions to them. In the present study, we employed bioinformatics tools to predict and eval-uate the structural model of interferon alpha/beta receptor 2 protein, based upon protein sequences for three different isoforms $(a, b$ and $c)$. Results showed that probability of interferon alpha/beta receptor 2 protein (isoform $\mathrm{a}, \mathrm{b}$ and $\mathrm{c}$ ) localization is highest in the plasma membrane. These results were also supported by the presence of transmembrane alpha helical regions. Structural characteristics and cellular localization are important features for INFs bindingand respective downstream signalling for various functions, ${ }^{16}$ particularly cell proliferation, signal transduction, immune system processing, ${ }^{17,18}$ and stress responses. ${ }^{12}$ Our study is limited to the in silico analysis and need wet lab confirmation, but results of this analysis will be helpful in future, to understand the 3D structural basis for any drug related interactions, ${ }^{19}$ of human interferon alpha/ beta receptor 2 isoforms.

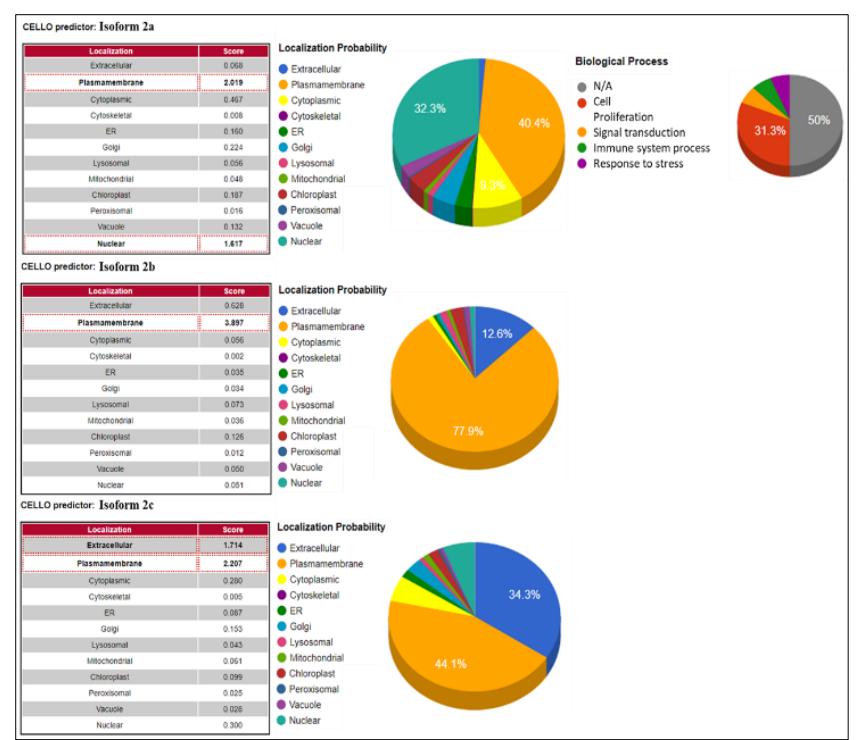

Figure-4:Prediction of the subcellular localization of human IFNAR-2 (isoform $a, b$ and c) protein.

\section{CONCLUSION}

This study predicted the tertiary structural dimensions of human IFNAR-2 protein, including the specific topological domains that contribute towards the subcellular compartmentalization andfunctional characteristics.

Conflict of Interest: None. 


\section{Silico Characterization}

\section{Authors' Contribution}

GAT: Designed and conducted study manuscript write-up, AJ: Designed and conducted study analysis, HBA: Review of literature, AS; Experimental data analysis and manuscript write-up.

\section{REFERENCES}

1. Novick D, Cohen B, Rubinstein M. The human interferon alpha/ beta receptor: characterization and molecular cloning. Cell 1994; 77(3): 391-400.

2. Lutfalla G, Holland SJ, Cinato E, Monneron D, Reboul J. Mutant U5A cells are complemented by an interferon-a receptor subunit generated by alternative processing of a new member of a cytokine receptor gene cluster. EMBO J 1995; 14(20): 5100-5108.

3. Owczarek CM, Hwang SY, Holland KA, Gulluyan LM, Tavaria $\mathrm{M}$, Weaver B, et al.Cloning and Characterization of Soluble and Transmembrane Isoforms of a Novel Component of the Murine Type I Interferon Receptor, IFNAR 2. J Biol Chem 1997; 272(38): 23865-23870.

4. De Weerd NA, Samarajiwa SA, Hertzog PJ. Type I Interferon Receptors: Biochemistry and Biological Functions. J Biol Chem 2007; 282(28): 20053-20057.

5. Stanifer ML, Pervolaraki K, Boulant S. Differential regulation of Type I and Type III interferon signaling. Int J Mol Sci 2019; 20(6): 1445.

6. Chill JH, Quadt SR, Levy R, Schreiber G, Anglister J. The human type $\mathrm{i}$ interferon receptor: NMR structure reveals the molecular basis of ligand binding. Struct (Lond) 2003; 11(7): 791-802.

7. Walter MR. The role of structure in the biology of interferon signalling. Front Immunol 2020; 11(1): 606489.

8. Trali GA, Javed A, Sadiq A. An in silico primary and secondary structure prediction of human interferon alpha receptor 2 protein. Pak J Physiol 2018; 14(1): 40-43.
9. Biasini M, Stefan B, Andrew W, Konstantin A, Gabriel S, Tobias S, et al. SWISS-MODEL: Modelling protein tertiary and quarternary structure using evolutionary information. Nucleic Acids Res 2014; 42(W1): W252-W258.

10. Sadiq A, Hayat MQ. In silico characterization of human serotonin receptor 1A protein. Int J Biosci 2018; 12(2): 338-345.

11. Spetale F, Arce D, Krsticevic F, Bulacio P, Tapia E. Consistent prediction of GO protein localization. Sci Rep 2018; 8(1): 7757.

12. Schneider WM. Interferon-stimulated genes: a complex web of host defenses. Annu Rev Immunol 2014; 32(2): 513-545.

13. Padariya M, Sznarkowska A, Kote S, Gómez-Herranz M, Mikac $\mathrm{S}$, Pilch M, et al. Functional interfaces, biological pathways, and regulations of Interferon-Related DNA Damage Resistance Signature (IRDS) genes. Biomol 2021; 11(5): 622.

14. Cook LE, Locke MC, Young AR, Monte K, Hedberg ML, Shimak $\mathrm{RM}$, et al. Distinct roles of interferon alpha and beta in controlling chikungunya virus replication and modulating neutrophil-mediated inflammation. J Virol 2019; 94(1): e00841.

15. Peters SO, Hussain T, Adenaike AS, Hazzard J, Morenikeji OB, Donato $\mathrm{MD}$, et al. Evolutionary pattern of interferon alpha genes in Bovidae and genetic diversity of IFNAA in the Bovine genome. Front Immunol 2020; 11(1): 2316.

16. Clayton E, Munir M. Fundamental characteristics of Bat interferon systems. Front Cell Infect Microbiol 2020; 10(2): 527921.

17. Park A, Iwasaki A. Type I and type III interferons - induction, signaling, evasion, and application to combat COVID-19. Cell host Microbe 2020; 27(6): 870-878.

18. Wang BX, Fish EN. Global virus outbreaks: Interferons as 1st responders. Semin Immunol 2019; 43(2): 101300.

19. Mendoza JL, Escalante NK, Jude KM, Sotolongo BJ, Su L, Horton $\mathrm{TM}$, et al. Structure of the IFNY receptor complex guides design of biased agonists. Nature 2019; 567(7746): 56-60. 